\title{
Carbon sequestration potential of community forests: $A$ comparative analysis of soil organic carbon stock in community managed forests of Far-Western Nepal
}

\section{Rajeev Joshi a,b,*, Hukum Singh c, Ramesh Chhetri d, Saroj Raj Poudel a, Sandip Rijal a}

a Forest Research Institute (Deemed to be) University, Dehradun-248195, Uttarakhand, India

b Department of Forestry, Amity Global Education (Lord Buddha College), CTEVT, Tokha -11, Kathmandu-44600, Nepal

c Forest Ecology and Climate Change Division, Forest Research Institute, Dehradun-248006, Uttarkhand, India

${ }^{d}$ Kali Gandaki polytechnic Institute, CTEVT, Ghiring 1, Tanahun-33900, Nepal

\section{Article Info}

Received : 30.06.2020

Accepted : 09.11.2020

\begin{abstract}
Assessment of soil organic carbon (SOC) pool is an essential pace for understanding the carbon sequestration potential (CSP) of the soil system as a mitigation strategy and also investigate that they act as a source or sink for the atmospheric $\mathrm{CO}_{2}$ subject to the level of saturation. Improved CSP has been recognized as one of the possible solutions for mitigating climate change. The CSP of soil system for the community forests (CFs) in Nepal is not well recognized. Therefore, a study was conducted in two community-managed forests viz Ganesh (degraded) and Ramnagar (non-degraded) CFs situated in the Kanchanpur district of Nepal to quantify the SOC and Bulk density (BD). For determining SOC, systematic sampling with a sampling intensity of $0.5 \%$ was used for collecting altogether 189 soil samples from both the CFs. In addition, the soil samples from varying depths $(0-10,10-20$, and $20-30 \mathrm{~cm})$ of each soil profile were collected from each sampling plot. The mean SOC observed upto $30 \mathrm{~cm}$ soil depth in Ganesh and Ramnagar CF was $42.55 \pm 3.10 \mathrm{t} \mathrm{ha}^{-1}$ and $54.21 \pm 3.59 \mathrm{t} \mathrm{ha}^{-1}$ respectively. While, maximum SOC was noticed at $0-10 \mathrm{~cm}$ whereas minimum at $20-30 \mathrm{~cm}$ in both the CFs. Moreover, SOC decreased and bulk density increased with increasing soil depth in both the CFs. SOC and BD was negatively correlated in both CFs. The total SOC pool exhibited a significant $(p<0.05)$ difference between the two CFs. Hence, the outcome of study shows that the both CFs has enormous potential to sequester the atmospheric concentration of $\mathrm{CO}_{2}$ into soil. With this concern, the participation of local people in sustainable management of community forests enhance the soil quality and meets strategy to mitigate the climate change.
\end{abstract}

Keywords: Bulk density, carbon sequestration potential, community forest, soil depth, soil organic carbon.

(c) 2021 Federation of Eurasian Soil Science Societies. All rights reserved

\section{Introduction}

Carbon sequestration through the soil system is recognized as a potential solution for climate change mitigation (Alidoust et al., 2018). The rapid increase in the atmospheric $\mathrm{CO}_{2}$ concentration could be diminished either by reducing emissions or removing atmosphere $\mathrm{CO}_{2}$ by sequestrating into the soil (IPCC, 2006). Forest ecosystem is known as the reservoir of carbon source that sequestered the carbon in vegetation and soil through the process of photosynthesis and respiration (Brown et al., 1996). Trees and soil are the major carbon pools that store more carbon than others in the forest ecosystem (Amir et al., 2018). According to the Global Forest Resource Assessment Report (FAO, 2020), the total forest carbon

\footnotetext{
* Rajeev Joshi Hukum Singh Ramesh Chhetri Saroj Raj Poudel Sandip Rijal

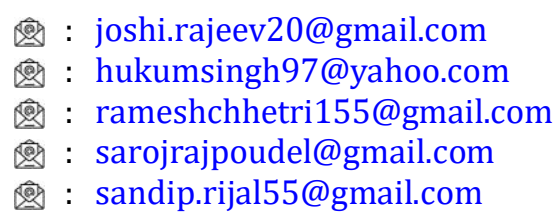

0000-0003-1106-9911 (Corresponding author) $0000-0003-2112-6182$ 0000-0003-2226-9468 0000-0001-9014-1779 0000-0002-6128-5754 
stock is 662 Giga tones and forest SOC contains 45\% of total forest carbon stock (297.9 Giga tones). Furthermore, SOC is the most important carbon pool in terrestrial ecosystems and plays a major role in carbon sequestration by increasing SOC in the terrestrial biosphere carbon pool (Ali et al., 2019; Hou et al., 2019). Out of the total global terrestrial carbon pools, $60 \%$ of the carbon has been shared by forests and soil only and the carbon pool in the soil is higher than the vegetation carbon pool (Winjum et al., 1992). Thus, it is necessary to understand that the forests and soil can be well managed to sequester or safeguard substantial amounts of carbon on the land (Sharma et al., 2011).

Based on the disturbances, the forests have been classified into two group's i.e., degraded and non-degraded forests (Joshi et al., 2020). Regarding the degraded forest, the disturbance may be natural or have an anthropogenic origin (Turner et al., 2003). Anthropogenic activities are notorious for major environmental changes leading to global warming (Aryal et al., 2017). Soil organic carbon (SOC) and carbon flux are greatly affected under the land-use pattern and soil management regime (Post and Kwon, 2008). In general, Nepal is known as the pioneer of the community forestry (CF) program in which forests are handed over to community Forest User Group (Pandit et al., 2009). It was initiated to promote livelihood along with controlling environmental degradation via sustainable forest management where authority and management of forest rest upon communities in coordination with the government and other multiple stakeholders (Gautam et al., 2008). Increasingly, the recognized huge potential of CFs in carbon trading from the REDD+ mechanism can reward economic benefits for the country (Joshi et al., 2020). Meanwhile, UNREDD (2014) indicated that REDD+ may bring between \$20-86 million per year to Nepal. Additionally, most of the scientific work are concentrated on carbon and SOC stocks at different landscapes and community forest (Shrestha et al., 2004; Shrestha and Singh, 2008; Magar et al., 2020) However, there are very limited studies on soil carbon sequestration potential of community forest. Therefore, this study was intended to address the existing gap of literature by assessing the soil carbon sequestration potential of two community forests.

\section{Material and Methods}

\section{Study area}

The research was conducted in Ganesh and Ramnagar community forests of Kanchanpur district, Nepal (Figure 1). Kanchanpur district lies in Mahakali zone with the coordinates of $28.8372{ }^{0} \mathrm{~N}$ latitude and $80.3213^{\circ} \mathrm{E}$ longitude at the south-west part of Far-Western Province. Ganesh CF is situated in Bedkot Municipality- 6 whereas; Ramnagar CF is in Belauri Municipality Ward Number 5 with an area of 434.48 and 197.16 ha, respectively. Each community forest user groups were handed forest at different time period i.e., Ganesh CF in year 2001 A.D. whereas Ramnagar in 2010 A.D. Both CFs are found with altitude ranging from 120-300 metres above sea level. Ganesh CF is facing towards the northern aspect (Churia foothills) and Ramnagar CF on the southern aspect of Terai belts. The soil of Ganesh CF was alluvial, sandy, and graveled whereas the soil of Ramnagar CF varies from alluvial to clay loam and is mostly black. Ganesh CF consists of scattered stands of mixed Sal broad-leaved natural forests whereas Ramnagar CF mainly consists of natural Sal forests (Joshi et al., 2019).

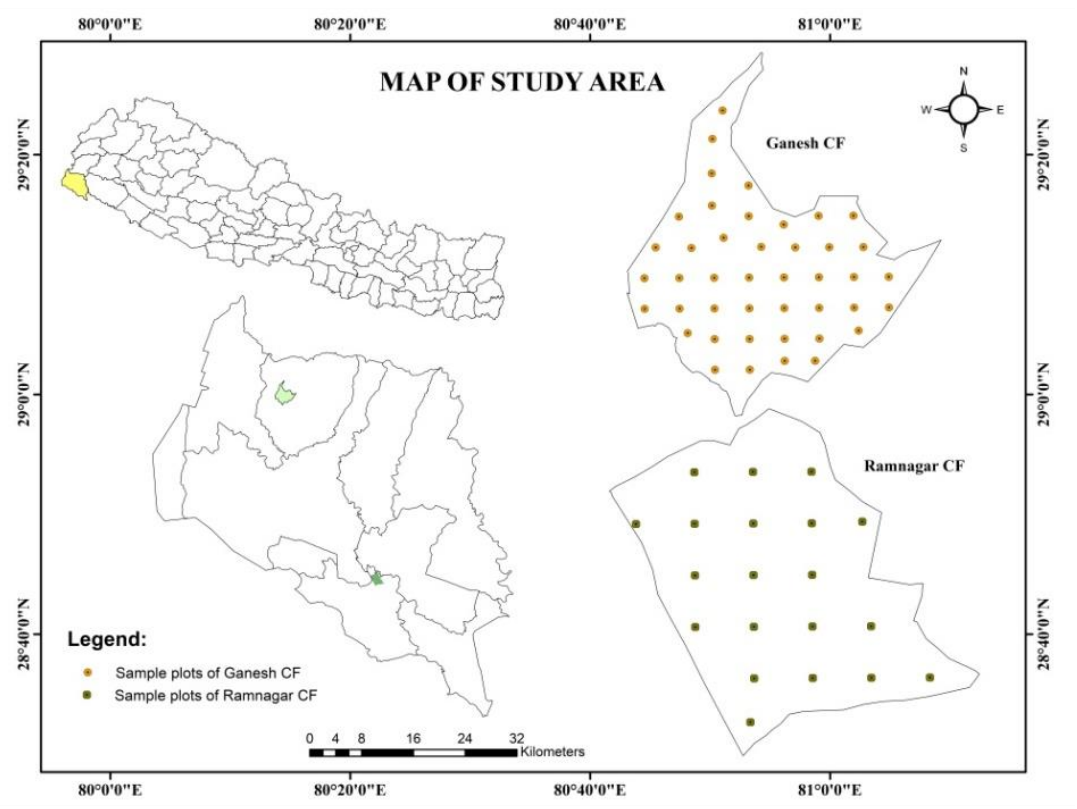

Figure 1. Map of the study area 
Under this study, two CFs were divided into degraded (Ganesh CF) and non-degraded (Ramnagar CF) categories based on certain parameters (For detail explanation see Joshi et al., 2020). The degraded forest was characterized by barren and riverine areas with the presences of few trees, shrubs, and grasses susceptible to soil erosion (Ghimire et al., 2018). The study area of Ganesh CF was known as degraded CF due to the occurrence of the landslide, soil erosion, and deforestation representing. The various tending operations and major management activities are undertaken sustainably in Ramnagar CF compare to Ganesh CF. Besides, fire lines are constructed in each sub-compartments in Ramnagar CF under the scientific forest management (SFM) approach (Joshi et al., 2020). The average maximum and minimum temperature of the district is $38^{\circ} \mathrm{C}$ (June) and $13^{\circ} \mathrm{C}$ (January) with a mean annual precipitation of $1512.12 \mathrm{~mm}$ (Joshi et al., 2020).

\section{Data collection and analysis}

\section{Sample plot design}

In selected CFs, boundary surveys were carried out using GPS with the help of the forest guards and members of the forest user groups to record the latitude, longitude, and altitude of each boundary point. For the soil survey, a circle of 0.56 meter radius was made for the collection of samples as per the protocol of ANSAB (2010). Systematic sampling with a sampling intensity of $0.5 \%$ was applied for this study. For the systematic sampling, ArcMap 10.5 software was used to lay a total of 63 (43 in Ganesh CF and 20 in Ramnagar CF) sample plots though fishnet. The points generated in ArcMap was loaded in GPS and sampled were obtained from the predetermined location with the accuracy of \pm 5 meters.

Ganesh Community Forest

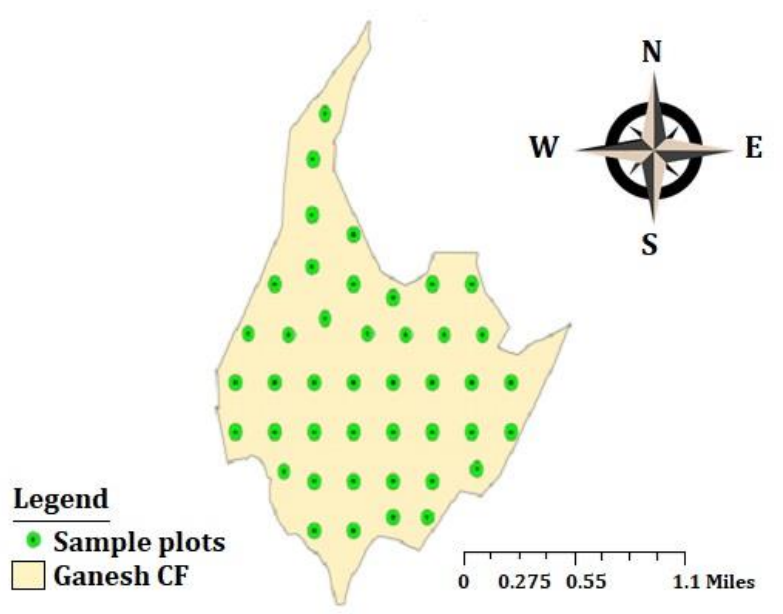

Ramnagar Community Forest

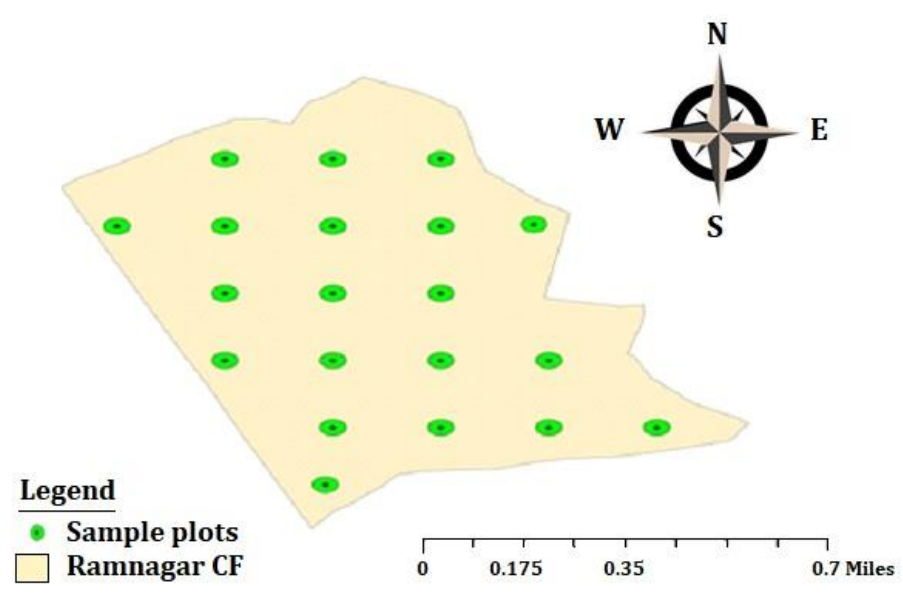

Figure 2. Sample plot design for both community forests

\section{Soil sampling}

For the estimation of soil organic carbon stock, the soil profile was dug out near the center of each sampling site up to $30 \mathrm{~cm}$ depth. From each community's forests, two replication of soil samples of each sample plot were collected up to $30 \mathrm{~cm}$ depth $(0-10 \mathrm{~cm}, 10-20 \mathrm{~cm}$, and $20-30 \mathrm{~cm})$ by using a soil auger. Altogether 189 soil samples were collected from each sample plot $(43 \times 3$ in Ganesh CF and $20 \times 3$ in Ramnagar CF) with different soil depths. To determine bulk density, a metal core ring sampler of $210 \mathrm{gm} \mathrm{cm}^{-3}$ was used to extract soil samples at 0-10 cm, 10-20 cm, and 20-30 cm depths. Finally, the extracted fresh soil samples were bagged in plastic bags and tightly closed by plastic rubber with proper labeling and transported to the laboratory of Forest Research Institute (FRI), Dehradun, India. The samples were collected during December 2018.

\section{Laboratory analysis \\ Bulk density}

Soil samples were oven-dried at the temperature of $105^{\circ} \mathrm{C}$ until a constant weight was recorded. The ovendried soil was then passed through a $2 \mathrm{~mm}$ sieve to segregate stones which helps to determine moisture correction. Finally, the total amount of coarse fragments were estimated from each soil sample collected from different sample sites and subtracted from the soil weight to get a precise soil weight. According to Pearson et al. (2007) bulk density was calculated as follows:

Bulk density $(\mathrm{gm} / \mathrm{cc})=\frac{\text { Oven dry weight of soil }(\mathrm{gm})}{\text { Volume of the soil }(\mathrm{cc})}$ where, 


\section{Soil Organic Carbon (SOC)}

Soil samples were collected from 0-10, 10-20, and 20-30 cm depths and one composite from each sample plot. Bagged samples were transferred to the pre-weighed sampling bags. Each Soil samples were room dried for 10 days, grind into small particles, and passed through a $0.2 \mathrm{~mm}$ sieve. For SOC determination, the titrimetric method given by Walkley and Black (1934) was used. The SOC percent (\%) was calculated by using the following formula:

Carbon $(\%)=3.951 / \mathrm{g}[1-\mathrm{T} / \mathrm{S}]$

where, $\mathrm{g}=$ Weight of sample in gram,

$\mathrm{T}=$ Total consumed volume of ferrous solution in sample titration $(\mathrm{ml})$, $\mathrm{S}=$ Total consumed volume of ferrous solution in blank titration (ml)

The carbon stock density of soil organic carbon was then calculated as follows:

where,

Soil Organic Carbon $(\mathrm{SOC})=\S \mathrm{xdx} \% \mathrm{C} \quad \mathrm{SOC}=$ soil organic carbon stock per unit area $\left(\mathrm{t} \mathrm{ha}^{-1}\right)$,

$\S=$ soil bulk density $\left(\mathrm{gm} \mathrm{cm}^{-3}\right)$,

$\mathrm{d}=$ the total depth at which the sample was taken $(\mathrm{cm})$

$\% \mathrm{C}=$ carbon concentration $(\%)$

Further, it was expressed in ton per hectare.

\section{Statistical analysis}

The SOC of various depths was estimated by soil organic carbon concentration, soil bulk density, soil depth, and proportion of gravels. Statistical analysis such as univariate analysis under the General Linear Model and Duncan's multiple range test was performed to study the significant difference between soil variables of two community forests with various depths $(p<0.05)$. All these statistical analysis was done by using the SPSS and R software.

\section{Correlation between Soil Organic Carbon (SOC) and Bulk Density (BD)}

Pearson's correlation was applied for the both parameter of SOC and BD. The correlation effect of both community forests on SOC and BD was analyzed by comparison of their mean values. Mean values of SOC and BD were determined by taking an average of soil depth up to $30 \mathrm{~cm}(0-10 \mathrm{~cm}, 10-20 \mathrm{~cm}$, and 20-30 cm) of each sample plot of both community forests. Multiple comparisons of mean values for each variable (SOC and BD) were carried out by using R software and Microsoft Excel 2010 (Bhandari and Bam, 2014).

\section{Results}

\section{Bulk density (BD)}

The mean value of bulk density from all soil samples for each soil depth and individual CFs was calculated. The mean BD for both CFs increased slightly with increasing soil depth (Figure 3). On average, the bulk density of Ramnagar CF (non-degraded) was higher as compare to Ganesh CF (degraded). Table 1 shows bulk density mean value varies from 1.24 to $1.44 \mathrm{gm} \mathrm{cm}^{-3}$.

Table 1. Average bulk density ( $\left.\mathrm{gm} \mathrm{cm}^{-3}\right)$ at various depths

\begin{tabular}{lcc}
\hline & & Mean Bulk Density $\left(\mathrm{gm} \mathrm{cm}^{-3}\right) \pm$ S.E \\
\cline { 2 - 3 } Depth $(\mathrm{cm})$ & Ganesh CF & Ramnagar CF \\
\hline $0-10$ & $1.24 \pm 0.02$ & $1.33 \pm 0.03$ \\
$10-20$ & $1.25 \pm 0.02$ & $1.41 \pm 0.02$ \\
$20-30$ & $1.29 \pm 0.03$ & $1.44 \pm 0.02$ \\
\hline
\end{tabular}

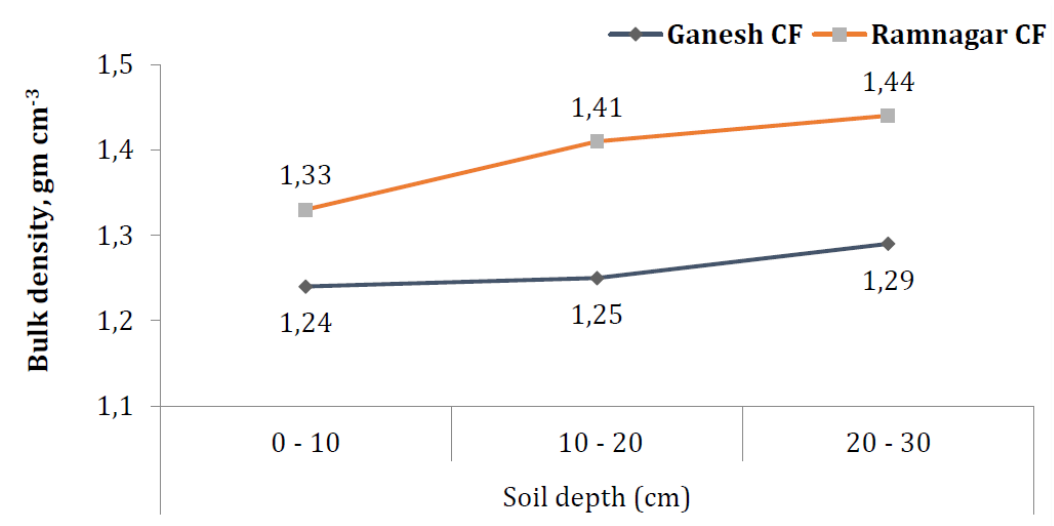

Figure 3. Graph showing the average amount of bulk density in each horizon 
From the univariate analysis, it can be inferred that there is a significant impact of depth on bulk density for Ramnagar CF as $p<0.05$. Further, Duncan's test of homogeneity was conducted to assess the relationship between these factors (Table 2). There was significant difference between values (subset 1) for depth 0-10 $\mathrm{cm}$ to values (subset 2) of bulk density for the ranges $10-20 \mathrm{~cm}$ and $20-30 \mathrm{~cm}$ but found insignificant between these later values of subset 2 in Ramnagar CF. However, in Ganesh CF, there was no significance difference between the values of bulk density (Subset 1) for all the different ranges (0-10, 10-20 and 20-30), (Table 2). From Duncan's subsets values it can be deduced that with increasing depth, bulk density is increasing significantly ( $p \leq 0.05$ ) but does not found differ considerably between $10-20 \mathrm{~cm}$ and $20-30 \mathrm{~cm}$ depth.

Table 2. Duncan's test for bulk density in both CFs

\begin{tabular}{|c|c|c|c|c|}
\hline \multirow{2}{*}{ Soil Depth $(\mathrm{cm})$} & \multicolumn{2}{|c|}{ Ganesh CF } & \multicolumn{2}{|c|}{ Ramnagar CF } \\
\hline & No. of obs. & Subsets for BD & No. of obs. & Subsets for BD \\
\hline $0-10$ & 43 & $1.2374 \mathrm{~A}$ & 20 & $1.3295 \mathrm{~A}$ \\
\hline $10-20$ & 43 & $1.2544 \mathrm{~A}$ & 20 & $1.4110 \mathrm{~B}$ \\
\hline $20-30$ & 43 & $1.2849 \mathrm{~A}$ & 20 & $1.4375 \mathrm{~B}$ \\
\hline$P_{\alpha=0.05}$ & \multicolumn{2}{|c|}{0.175} & \multicolumn{2}{|c|}{0.459} \\
\hline
\end{tabular}

\section{Soil organic carbon}

The study site shows the variable of SOC percent ranges from $0.95 \%$ to $1.80 \%$. The higher SOC $(1.80 \pm$ $0.14 \%)$ was found at the topsoil $(0-10 \mathrm{~cm})$ in the Ramnagar CF and lowest SOC $(0.95 \pm 0.07 \%)$ at the depth of 20-30 cm in the same CF (Table 3). Results demonstrated that as the depth increase SOC percentage decrease in both CFs.

Table 3. Average Soil Organic Carbon (\%) at various depths

\begin{tabular}{lcc}
\hline \multirow{2}{*}{ Soil Depth $(\mathrm{cm})$} & \multicolumn{2}{c}{ Mean Soil Organic Carbon (\%) \pm S.E } \\
\cline { 2 - 3 } $0-10$ & Ganesh CF & Ramnagar CF \\
$10-20$ & $1.45 \pm 0.12$ & $1.8 \pm 0.14$ \\
$20-30$ & $1.2 \pm 0.1$ & $1.21 \pm 0.11$ \\
& $1.08 \pm 0.11$ & $0.95 \pm 0.07$ \\
\hline
\end{tabular}

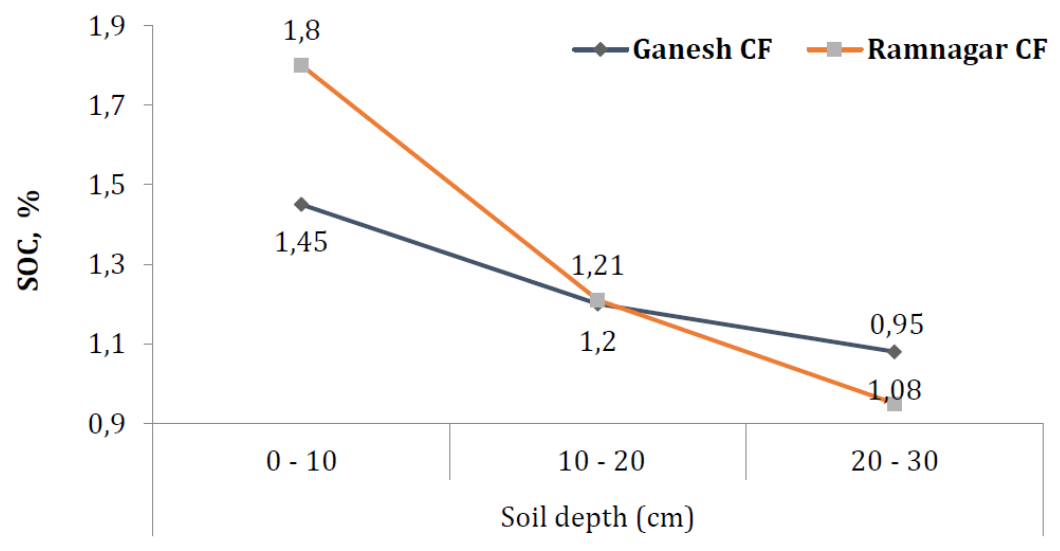

Figure 4. Average soil organic carbon at various depths

\section{Soil organic carbon stock}

In the present study, total SOC for Ganesh and Ramnagar CF was estimated to be $127.64 \mathrm{t} \mathrm{ha}^{-1}$ and $162.64 \mathrm{t}$ ha $^{-1}$ respectively. While, the average SOC was estimated to be $42.55 \pm 3.10 \mathrm{t} \mathrm{ha}^{-1}$ at Ganesh CF. Similarly, the maximum SOC stock was found to be $50.51 \mathrm{t} \mathrm{ha}^{-1}$ at 0-10 cm depth and minimum (36.75 $\left.\mathrm{t} \mathrm{ha}^{-1}\right)$ in $20-30 \mathrm{~cm}$ depth. However, in case of Ramnagar CF, the mean SOC stock was calculated $54.21 \pm 3.59 \mathrm{t} \mathrm{ha}^{-1}$. SOC was highest (70.81 tha-1) for soil depth $0-10 \mathrm{~cm}$ and lowest (41.15 $\left.\mathrm{t} \mathrm{ha}^{-1}\right)$ for 20-30 cm. So, the result showed that the decreasing rate of carbon content as it goes to deeper (Figure 5). Data revealed that SOC of Ramnagar CF is more in comparison to Ganesh CF.

From the univariate analysis, it was concluded that there are significant changes of SOC with soil depth for both CFs $(p \leq 0.05)$. Moreover, in both CFs, Duncan's test of homogeneity revealed no significant difference between values 10-20 and 20-30 cm (subset 2). The value of (subset 1) for depth $0-10 \mathrm{~cm}$ differs significantly from those two different depths. Duncan's subsets values revealed that with increasing depth, SOC was decreasing but does not differ significantly between 10-20 and 20-30 cm depth (Table 5). 
Table 4. Total amount of soil organic carbon with respect to its soil depth

\begin{tabular}{cccc}
\hline S.N. & Soil Depth $(\mathrm{cm})$ & \multicolumn{2}{c}{ Mean Soil Organic Carbon (t ha-1) \pm S.E } \\
\cline { 3 - 4 } & & Ganesh CF & Ramnagar CF \\
\hline 1 & $0-10$ & $50.51 \pm 3.74$ & $70.81 \pm 5.30$ \\
2 & $10-20$ & $40.38 \pm 3.15$ & $50.68 \pm 4.51$ \\
3 & $20-30$ & $36.75 \pm 3.41$ & $41.15 \pm 2.92$ \\
& Sum total & 127.64 & 162.64 \\
& Average total & $42.55 \pm 3.10$ & $54.21 \pm 3.59$ \\
\hline
\end{tabular}

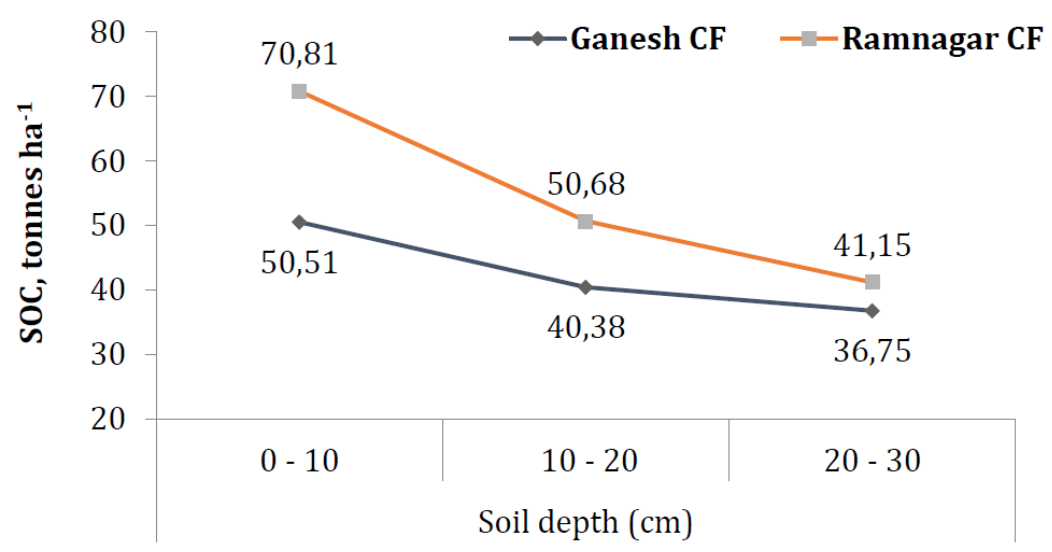

Figure 5. Graph showing the amount of carbon stock in each horizon

Table 5. Duncan's test for SOC in both CFs

\begin{tabular}{|c|c|c|c|c|}
\hline \multirow{2}{*}{ Soil Depth $(\mathrm{cm})$} & \multicolumn{2}{|c|}{ Ganesh CF } & \multicolumn{2}{|c|}{ Ramnagar CF } \\
\hline & No. of obs. & Subsets for BD & No. of obs. & Subsets for BD \\
\hline $0-10$ & 43 & $50.51 \mathrm{~A}$ & 20 & $70.81 \mathrm{~A}$ \\
\hline $10-20$ & 43 & $40.38 \mathrm{~A}$ & 20 & $50.68 \mathrm{~B}$ \\
\hline $20-30$ & 43 & $36.75 \mathrm{~A}$ & 20 & 41.15B \\
\hline$P_{\alpha}=0.05$ & \multicolumn{2}{|c|}{0.457} & \multicolumn{2}{|c|}{0.127} \\
\hline
\end{tabular}

\section{Correlation between SOC and BD}

In the studied CFs, SOC is found negatively correlated with bulk density which shows that the present study is in favor of the universally accepted concept (Table 6). A perfect negative correlation was observed between SOC and BD in both community forests through multiple comparison of their mean values for each variable (Figure 6 and 7).

Table 6. Correlation between SOC $\left(\mathrm{t} \mathrm{ha}^{-1}\right)$ and BD $\left(\mathrm{gm} \mathrm{cm}^{-3}\right)$ of both community forests (CF)

\begin{tabular}{lcccccc}
\hline S.N. & Community forests & No. & d.f & t-value & $p$-value & ${ }^{*}$ Correlation coefficient \\
\hline 1 & Ganesh CF & 43 & 41 & -3.6543 & 0.0007 & -0.4956 \\
2 & Ramnagar CF & 20 & 18 & -0.1730 & 0.8646 & -0.0407 \\
\hline
\end{tabular}

Where, ${ }^{*}$ Correlation is significant at 0.05 level or $95 \%$ confidence interval. No. = number of observations

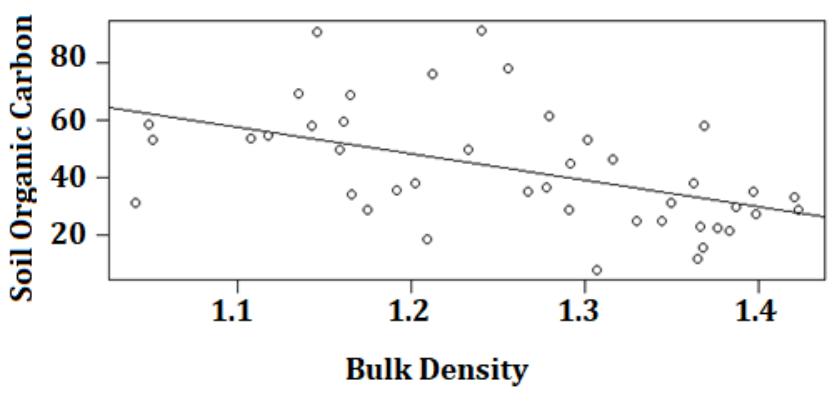

Figure 6. SOC content $\left(\mathrm{t} \mathrm{ha}^{-1}\right)$ and $\mathrm{BD}\left(\mathrm{gm} \mathrm{cm}^{-3}\right)$ of Ganesh CF

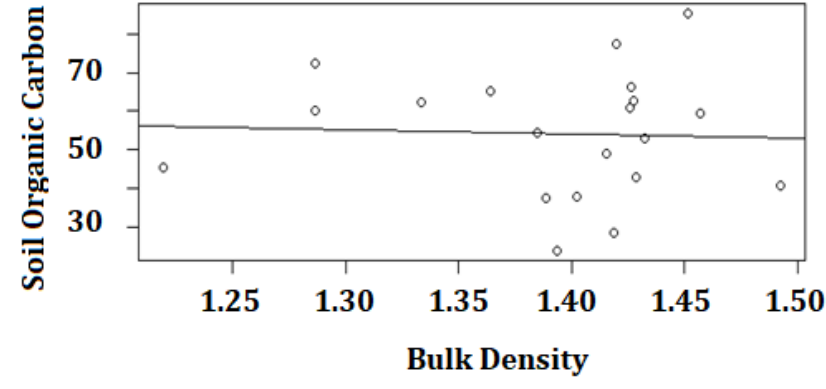

Figure 7. SOC content $\left(\mathrm{t} \mathrm{ha}^{-1}\right)$ and $\mathrm{BD}\left(\mathrm{gm} \mathrm{cm}^{-3}\right)$ of Ramnagar CF 


\section{Discussion}

Soil organic carbon is an indicator of soil quality that correlates with climate and land cover types such as forest, shrubland, and grassland (Chaudhari et al., 2013; Wu et al., 2017). While, there has been considerable agreement on the linkage between forest degradation and reduction in soil properties such as lower soil organic carbon and bulk density which is increased due to compaction (Sanji et al., 2020). Likewise, Morisada et al. (2004) suggested that the soil compaction due to weight or disturbance, consolidation, soil aggregates, and soil fauna has an impact on soil BD but it is inversely proportional to SOC content in natural forest. The parameters selected for this research includes soil BD and SOC. Finally, this study adds new empirical evidence that all tested variables of two community forests represent significant variation.

\section{Soil bulk density}

In the present study, distinct variation in the BD was observed with concerning soil depths at both the CFs. The diagnostic showed that the topsoil layer indicates lower BD. More positively, previous studies also suggested that low soil BD in the upper horizons of the soil is due to the existence of high organic matter in the soil facilitating plant roots (Mfaume et al., 2019). Likewise, the present research finding revealed that the mean BD for both CFs (ranging from 1.24 to $1.44 \mathrm{gm} \mathrm{cm}^{-3}$ ), increased with increasing soil depth but the BD of Ramnagar CF was higher as compare to Ganesh CF for all horizons. However, Duncan's results suggest that there was no significant difference between values (subset 2) of bulk density for the ranges $10-20 \mathrm{~cm}$ and 20-30 cm but values (subset 1) for depth 0-10 cm differ significantly from those two different depth in Ramanagar CF whereas in Ganesh CF, there was no significance difference between the values of bulk density (subset 1 ) for all the different ranges (0-10, 10-20 and 20-30). Further, less variation was observed in bulk density among soil horizons in degraded Ganesh CF may be an indication of soil compaction. Additionally, mounting evidence of various study mention that a agradual increase in soil bulk density with an increase in soil depth is also evident under all forest and lower bulk density in the uppermost layers indicates soil health for plant growth (Raddad and Luukkanen, 2007; Shrestha, 2009a,b; Ghimire et al., 2018; Adhikari and Ghimire, 2019). Apart from it, the study conducted by Pandey et al. (2019) represent the reciprocal relationship between SOC and bulk density in soils of three community forests of Far Western Nepal.

\section{Soil Organic Carbon}

SOC is a major constituent in forest soils and ecosystems. SOC accretion and disintegration rates have a direct influence on terrestrial ecosystem carbon sequestration and comprehensive carbon stability. More specifically, understanding SOC allocation in forest ecosystems is significant for improving soil quality and sustaining the forest production (Liu et al., 2016). Therefore we have analyzed the SOC for both community forests. During the study period, we observed that SOC content was higher at the upper layer $(0-10 \mathrm{~cm})$ and decreased as depth increase. Likewise, the higher the SOC content in the upper layer is due to high soil organic matter content. Meanwhile, Khanal et al. (2010) was coinciding the similar outcomes with our study. In fact, the evident of these findings was also supported by some researchers in the tropical forests of Nepal (Pandey and Bhusal, 2016; Ghimire et al., 2018;), they were observed declining SOC with increasing depth. Further, the mean SOC (up to $30 \mathrm{~cm}$ ) of Ganesh CF was lower than Ramnagar CF which was estimated to be $42.55 \pm 3.10 \mathrm{t} \mathrm{ha}^{-1}$ and $54.21 \pm 3.59 \mathrm{t} \mathrm{ha}^{-1}$ respectively. Notably, the SOC below $30 \mathrm{~cm}$ was excluded from the research site to maintain regularity in both CFs because to extract soil samples below $30 \mathrm{~cm}$ from each sample plots was not possible in Ganesh CF due to the presence of intact rock mass.

In our case study, the total SOC pool (up to $30 \mathrm{~cm}$ ) in Ganesh and Ramnagar CF was recorded up to $127.64 \mathrm{t}$ ha $^{-1}$ and 162.64 t ha $^{-1}$ respectively. Further, total SOC for Ganesh CF is close to the value estimated by Kafle (2019) i.e. 122.36 t ha $^{-1}$. While, compare with the previous studies Pandey and Bhusal (2016) of Sal (Shorea robusta) forests in the central region of Nepal, both the CFs of our study reported higher SOC. However, the researcher uses the different soil sampling methods (up to $1 \mathrm{~m}$ depth) and by comparing with our study area has less potential of carbon stock. Similarly, Shrestha and Singh (2008) and Shrestha (2009a,b) also indicated low SOC density than both Ganesh and Ramnagar CF. The variation in the total amount of SOC depends upon several biotic and abiotic factors such as faunal diversity, micro-climate, land use and management (Shrestha and Devkota, 2013). Further, Shrestha and Singh (2008) mention that the inputs of roots and leaf litter have a significant role in forest soil carbon dynamics. Moreover, the reduced soil organic carbon in the forested sites may be due to low vegetation cover and high anthropological activities (Yao et al., 2019). Nonetheless, the outcome results of Sheikh et al. (2009) study shows the declining rate of total SOC stock with an increase in altitude. Finally, It has been recommended that SOCs can play a vital role in land degradation/soil quality management and designing a carbon sequestration program making baseline data of SOC essential for the same (Nabiollahi et al., 2019). Thus forest management in terms of carbon sequestration, Ganesh CF has to take some additional measures to increase soil organic carbon. 


\section{Conclusion}

The SOC stored in the two different CFs were reported differently. In relation to soil depth, SOC was found to be inversely proportional while BD was found to be directly proportional to it. Both SOC and BD of Ramnagar CF were higher than those of Ganesh CF, and this contributed to the higher SOC stock in Ramnagar CF. The mean SOC in the Ganesh (degraded) CF was $42.55 \mathrm{t} \mathrm{ha}^{-1}$ whereas; the value was 54.21 t ha1 in the Ramnagar CF (non-degraded) measured up to the depth of $30 \mathrm{~cm}$. The topsoil is accumulated with increased SOC rather than lower profile in both forest suggesting forest management for retention of organic matter on forest floor. The presence of sandy soil in underneath may be the cause of low soil carbon content in the Ganesh CF. Statistically, the relationship between SOC and BD was tested negatively correlated. These findings suggest that the amount of SOC recorded higher at the Ramnagar (non-degraded) CF than Ganesh (degraded) CF. As per the result, we can conclude that both CFs has remarkably stored carbon serving for climate change mitigation. Finally, improved management of community forest for increased soil carbon sequestration could be a promising strategy to halt climate change.

\section{Acknowledgements}

The authors are grateful to Director, Forest Research Institute, Dehradun, India, for providing laboratory facilities during the study period. We would like to express our heartfelt gratitude to all the CFUGs members for their significant contribution and support for the successful completion of this research work. Finally, the authors would also like thankful to Antrix Soni, Durgesh Dhami, Maheshwari Bhatta, Suman Shree Neupane, Shachi Pandey and Bharat Sharma for their concern support and kind cooperation during study period.

\section{References}

Adhikari, B.M., Ghimire, P., 2019. Assessment of soil organic carbon stock of churia broad leaved forest of Nawalpur District, Nepal. Grassroots Journal of Natural Resources 2 (1-2): 45-52.

Ali, A., Ashraf, M.I., Gulzar, S., Akmal, M., Ahmad, B., 2019. Estimation of soil carbon pools in the forests of Khyber Pakhtunkhwa Province, Pakistan. Journal of Forestry Research 31: 2313-2321.

Alidoust, E., Afyuni, M., Hajabbasi, M.A., Mosaddeghi, M.R., 2018. Soil carbon sequestration potential as affected by soil physical and climatic factors under different land uses in a semiarid region. Catena 171: 62-71.

Amir, M., Liu, X., Ahmad, A., Saeed, S., Mannan, A., Muneer, M. A., 2018. Patterns of biomass and carbon allocation across chronosequence of chir pine (Pinus roxburghii) forest in Pakistan: inventory-based estimate. Advances in Meteorology Article ID 3095891.

ANSAB, 2010. Report on forest carbon stock of community forest in three watersheds (Ludikhola, Kayarkhola, and Charnawati). Asia Network for Sustainable Agriculture and Bioresources, Federation of Community Forest Users, Nepal, International Centre for Integrated Mountain Development \& Norwegian Agency for Development Cooperation:. 49. Available at [Access date: 30.06.2020]: https://www.ansab.org.np/index.php

Aryal, B., Bhattarai, B. P., Pandey, M., Giri, A., 2017. Carbon sequestration and $\mathrm{CO}_{2}$ mitigation in a burned ecosystem of Pinus ruoxbrghii forest in Langtang National Park, Nepal. Tropical Plant Research 4 (2): 297-306.

Bhandari, S., Bam, S., 2014. Comparatives study of soil organic carbon (SOC) under forest, cultivated and barren Land: A Case of Chovar Village, Kathmandu. Nepal Journal of Science and Technology 14(2): 103-108.

Brown, S., Sathaye, J., Cannell, M., Kauppi, P. E., 1996. Mitigation of carbon emissions to the atmosphere by forest management. The Commonwealth Forestry Review 75 (1): 80-91.

Chaudhari, P. R., Ahire, D. V., Ahire, V. D., Chkravarty, M., Maity, S., 2013. Soil bulk density as related to soil texture, organic matter content and available total nutrients of Coimbatore soil. International Journal of Scientific and Research Publications 3 (2): 1-8.

FAO, 2020. Global Forest Resources Assessment 2020- Key findings. Food and Agriculture Organization of the United Nations, Rome, Italy. 16p. Available at [Access date: 30.06.2020]: http://www.fao.org/3/ca8753en/CA8753EN.pdf

IPCC, 2006. Revised IPCC guidelines for national greenhouse gas Inventories. Intergovernmental Panel on Climate Change (IPCC) Publication, Cambridge University Press, Cambridge.

Gautam, A. P., Karmacharya, M. B., Karna, B. K, 2008. Community Forestry, Equity and Sustainable Livelihoods in Nepal. Governing Shared Resources: Connecting Local Experience to Global Challenges, the Twelfth Biennial Conference of the International Association for the Study of Commons. 14-18 July 2008. Cheltenham, England.

Ghimire, P., Bhatta, B., Pokhrel, B., Kafle, G., Paudel, P., 2018. Soil organic carbon stocks under different land uses in Chure region of Makawanpur district, Nepal. SAARC Journal of Agriculture 16 (2): 13-23.

Hou, G., Delang, C., Lu, X., Gao, L., 2019. Soil organic carbon storage varies with stand ages and soil depths following afforestation. Annals of Forest Research 62(2): 3-20.

Joshi, R., Chhetri, R., Yadav, K., 2019. Vegeatation Analysis in community forests of Terai Region, Nepal. International Journal of Environment 8(3): 68-82.

Joshi, R., Singh, H., Chhetri, R., Yadav, R., 2020.Assessment of carbon sequestration potential in degraded and nondegraded community forests in Terai Region of Nepal. Journal of Forest and Environmental Science36 (2): 113121. 
Kafle, G., 2019. Vertical distribution of soil organic carbon and nitrogen in a tropical community forest of Nepal. International Journal of Forestry Research Article ID 3087570.

Khanal, Y., Sharma, R.P., Upadhyaya, C.P., 2010. Soil and vegetation carbon pools in two community forests of Palpa district, Nepal. Banko Janakari 20 (2): 34-40.

Liu, Y., Li, S., Sun, X., Yu, X., 2016. Variations of forest soil organic carbon and its influencing factors in east China. Annals of Forest Science 73: 501-511.

Magar, L. K., Kafle, G., Aryal, P., 2020. Assessment of soil organic carbon in tropical agroforests in the Churiya Range of Makawanpur, Nepal. International Journal of Forestry Research Article ID 8816433.

Mfaume, D.P., 2019. Pedological Characterization and fertility, assessment of mbimba substation soils under coffee production in Mbozi District, Tanzania. International Journal of Advances in Scientific Research and Engineering 5 (10): 221-236

Morisada, K., Ono, K., Kanomata, H., 2004. Organic carbon stock in forest soils in Japan. Geoderma 119 (1-2): 21-32.

Nabiollahi, K., Eskandari, S., Taghizadeh-Mehrjardi, R., Kerry, R., Triantafilis, J., 2019. Assessing soil organic carbon stocks under land-use change scenarios using random forest models. Carbon Management 10 (1): 63-77.

Pandey, H.P., Pandey, P., Pokhrel, S., Mandal, R., 2019. Relationship between soil properties and forests carbon: Case of three community forests from Far Western Nepal. Banko Janakari 29(1): 43-52.

Pandey, H.P., Bhusal, M., 2016. A comparative study on carbon stock in Sal (Shorea robusta) forest in two different ecological regions of Nepal. Banko Janakari 26(1): 24-31.

Pandit, B.H., Albano, A., Kumar, C., 2009. Community-based forest enterprises in Nepal: an analysis of their role in increasing income benefits to the poor. Small-scale Forestry 8 (4): 447-462.

Pearson, T.R.H., Brown, S.L., Birdsey, R.A., 2007. Measurement guidelines for the sequestration of forest carbon. United States Department of Agriculture, Forest Service, Northern Research Station, General Technical Report NRS-18. USA. 42p. Available at [Access date: 30.06.2020]: https://www.nrs.fs.fed.us/pubs/gtr/gtr_nrs18.pdf

Post, W.M., Kwon, K.C., 2000. Soil carbon sequestration and land-use change: processes and potential. Global Change Biology 6 (3): 317-327.

Raddad, E.Y., Luukkanen, O., 2007. The influence of different Acacia senegal agroforestry systems on soil water and crop yields in clay soils of the Blue Nile region, Sudan. Agricultural Water Management 87: 61-72.

Sanji, R., Kooch, Y., Rey, A., 2020. Impact of forest degradation and reforestation with Alnus and Quercus species on soil quality and function in northern Iran. Ecological Indicators 112: 106132.

Sharma, C.M., Gairola, S., Baduni, N.P., Ghildiyal, S.K., Suyal, S., 2011. Variation in carbon stocks on different slope aspects in seven major forest types of temperate region of Garhwal Himalaya, India. Journal of Biosciences 36 (4): 701-708.

Sheikh, M.A., Kumar, M., Bussmann, R.W., 2009. Altitudinal variation in soil organic carbon stock in coniferous subtropical and broadleaf temperate forests in Garhwal Himalaya. Carbon Balance and Management 4: 6.

Shrestha, B.M., Singh, B.R., 2008. Soil and vegetation carbon pools in a mountainous watershed of Nepal. Nutrient Cycling in Agroecosystems 81 (2): 179-191.

Shrestha, B.M., Sitaula, B. K., Singh, B.R., Bajracharya, R.M., 2004. Fluxes of $\mathrm{CO}_{2}$ and $\mathrm{CH}_{4}$ in soil profiles of a mountainous watershed of Nepal as influenced by land use, temperature, moisture and substrate addition. Nutrient Cycling in Agroecosystems 68 (2): 155-164.

Shrestha, B.P., 2009a. Carbon sequestration in broad leaved forests of mid-hills of Nepal: A case study from Palpa district. The Initiation 3: 20-29.

Shrestha, B.P., 2009b. Carbon sequestration in Schima-Castanopsis forest: A case study from Palpa District. The Greenery-A Journal of Environment and Biodiversity 7(1): 34-40.

Shrestha, B.P., Devkota, B.P., 2013. Carbon stocks in the oak and pine forests in Salyan district, Nepal. Banko Janakari 23(2): 30-36.

Turner, M.G., Collins, S.L., Lugo, A.L., Magnuson, J.J., Rupp, T.S., Swanson, F.J., 2003. Disturbance dynamics and ecological response: the contribution of long-term ecological research. BioScience 53 (1): 46-56.

UN-REDD, 2014. Understanding drivers and causes of deforestation and forest degradation in Nepal: potential policies and measures for REDD+. Discussion paper. The United Nations Collaborative Programme on Reducing Emissions from Deforestation and Forest Degradation in Developing Countries. 89p. Available at [Access date: 30.06.2020]: http://www.tinyurl.com/nepal-drivers-redd

Walkley, A., Black, I.A., 1934. An examination of Degtjareff method for determining soil organic matter and a proposed modification of the chromic acid titration method. Soil Science 37(1): 29-38.

Winjum, J.K., Dixon, R.K., Schroeder, P.E., 1992. Estimating the global potential of forest and agroforest management practices to sequester carbon. Water, Air, and Soil Pollution 64 (1-2): 213-227.

Wu, X., Fang, H., Zhao, Y., Smoak, J.M., Li, W., Shi, W., Sheng, Y., Zhao, L., Ding, Y., 2017. A conceptual model of the controlling factors of soil organic carbon and nitrogen densities in a permafrost-affected region on the eastern Qinghai-Tibetan Plateau. Journal of Geophysical Research: Biogeosciences 122: 1705-1717.

Yao, X., Yu, K., Deng, Y., Liu, J., Lai, Z., 2019. Spatial variability of soil organic carbon and total nitrogen in the hilly red soil region of Southern China. Journal of Forestry Research 31: 2385-2394. 